\title{
The Listener: Love of Money and How It Affects Someone's Life Especially in Decision Making and Personality
}

\author{
Michella Fellicia Setiawan \\ English Department, Faculty of Languages and Literature, Petra Christian University, Siwalankerto 121- \\ 131, Surabaya 60236, INDONESIA \\ Email: m11415031@john.petra.ac.id
}

\begin{abstract}
My screenplay The Listener is the story of Mike, a guy in his late 20s who loves money and thinks that money can buy happiness. My work's main idea revolves around loves of money and how it can lead into a bad decision. I used the theory Base of Materialism Theory from Belk and Measurement of Materialism and Money Attitude from Rimple, Srikant, Naseem, and Kumar to construct the personalities of the main character. The purpose of this creative thesis is to increase the awareness that money cannot buy happiness. I used crime as the genre and Heist Flicks as the subgenre because I see a lot of similarities and genre convention with my screenplay's subject matter of loves of money and money cannot buy someone's happiness. The story mostly tells about how Mike faces the hardship in making decisions due to his loves of money. Later, he focuses on his prestige by having lots of money. At the end, he realizes that friendship is more important than money.
\end{abstract}

Keywords: The Listener, Love of Money, Prestige, Materialism, Heist Flicks

\section{INTRODUCTION}

\section{Background of the Creative Work}

Money cannot buy happiness. This saying is really popular among young adults. Many youngsters post that quote on their social media and a lot of people like that post on Instagram or Facebook. However, it does not mean they stop think highly of money. Whether they realize it or not, people these days, especially in Indonesia become more and more materialistic because they value money more than they should do. From the data of Capgemini Asia Pacific Wealth Report in 2015, Indonesia ranks third in consuming branded things, beats Singapore and Hong Kong. The news proves that Indonesia is the biggest three in Asia which consumes luxury goods (Safiera, 2016). That is one of the proofs of materialism that happens in this society. Materialism itself is defined as the importance a person places on possessions and their acquisition as a necessary or desirable form of conduct to reach desired end states, including happiness (Mulyono, 2011).

To certain people, luxuries are necessities to make them look good and to tell people that they are above the level of standard. In this society, these past few years people believe that money is important just to show how good they are and to get an acknowledgement or status consumption. In a modern setting, status consumption means any consumption with the intent of showing off wealth to others when the good is publicly consumed - ranging from applying an expensive lipstick in public to driving an expensive car (Sheetz, n.d.).

Materialism drives people to forget the moral values in the society and causes the loss of moral values. Materialism makes people fail to understand the distinction between right choices and the wrong ones. One example is a corruption. People do corruption because they cannot see the right and wrong anymore, they lose their moral values and choosing money instead. KPK (Komisi Pemberantas Korupsi) says that there are 93 cases of corruption in 2017 (Taher, 2017). 
The number shows that the corruption rate in Indonesia is still high. That is why, in this thesis, I want to tell people, especially young adults, that this issue may seem simple but actually it is not.

I chose screenplay as my media to signify the issue, firstly, I am a visual person. The narration and the description of the screenplay needs to be precise and simple to understand. In a screenplay, I need to write or describe something on point and do not need to hyperbole things like in novels because it will show in film. It is easier for me to visualize something and pour it into exact words than beautiful words.

I also think, movie is a better medium to talk to the youth because most of youngsters like to watch movie and they can feel relate to it. Survey said that $79 \%$ Indonesian youngsters like to watch and just $6.3 \%$ youngsters who like to read (Alaydrus, 2017). Film industry in Indonesia is developing in a good way. According to the data, the number of viewers who watch Indonesian films has increase a lot. In 2017, the number of viewers of Indonesian movies is up to more or less 42 million people from 16 million people in the preceding years (Khrisnanda, 2018). This shows that film industry in Indonesia is growing rapidly and it sounds promising which means the demand of screenplay will increase.

To convey the message that I want to bring up, I choose crime as my genre because People often relate to crime genre because it tells people about the reality of the society and it says something important about social context (Spina, 2017). This genre develops into many new genres such as Heist Flicks, Legal Thriller, Private Eye, Tartan Noir, etc. However, specifically, I chose Heist Flicks, which is defined as a crime sub-genre which the lead characters, who break the law, are often portrayed as protagonist and the audience will keep rooting despite the fact that majority of the time they are breaking the law (Miyamoto, 2016).

The story of my creative work tells a story of a guy in his late 20s, Mike. At first, he does not have a job yet. One day, he finds his talent in listening to someone's story and he realizes that he can use the young girls who want to be listened to make money by making a website to chat and call. In a short time, he gets a lot of money. However, his family is still not satisfied by it and demand more. Then, he works harder and begins to spend his money to show off his luxurious life and he unconsciously keeps on craving for the money. Later, there is a girl who wants to meet him and gives him a lot of money. After a little bit consideration, he accepts the offer. However, he does not know that the meeting leads him to the big choices. The Listener struggles which path he should choose, telling the truth or getting the money.

\section{Statement of the Problem}

Materialism is not something new that happens in this society, people already knew about it, yet ignore it. This creative thesis tries to find out about the effects of being controlled by money, how money controls their life, and how someone realizes that money is not everything. In the context of my creative work, those questions become:

1. What the cause and the effects of being controlled by money are

2. How money controls Mike in making important decision

3. How Mike finally realizes that money is not everything

\section{Purpose of the Creative Work}

I want young adults to find out that money makes people becomes prestige oriented, difficult to choose between money and life's principle, and meaningful social interaction can make people 
realizes that money is not everything. In the context of my creative work, these are the answers of the questions above:

1. Because of his Aunt who keeps telling him about how money is everything, Mike becomes prestige oriented that leads him to bad decisions.

2. Mike finds it difficult to choose between saving someone's life and getting more money because he starts to enjoy his luxurious life.

3. At the end, the ragtag crew shows the true friendship to Mike and makes him realize that money is just a tool of transaction.

\section{Significance of the Creative Work}

Through this screenplay, I want my audiences, especially young adults, be more aware of materialism so that they can avoid it in the future, or at least they are trying to change their mindset to become a better generation. The suitable market for this screenplay is young adults, may be ranging between early 20 s to mid 30s. I want to influence the mindset of how bad materialism is to the young adults because young adults are the next generation of this country, so I want to give them positive way of thinking. This creative work connects with my target audiences because it uses crime genre that is famous at all ages and brings up the issue that is relatable for young adults these days, especially in Indonesia.

\section{Methodology}

The method of data gathering that I used in making this creative work is secondary, For this method, I searched and read the screenplays that are similar to my creative work, so I have the guidelines and can get a lot of information from there. Mostly, the screenplays that I read are around crime screenplays and materialism screenplays. Besides reading the screenplays, I also looked for information through journals and thesis, I gathered the data to strengthen my issue and my background. The journals and thesis mostly about materialism and the theory of materialism. I also searched some data from government website that give numbers or data from survey that has been done by the government. The methodology leads me to the sources that can help me understand more about the issue that I brought up, materialism, for instance, the meaning, the effects, the concepts of materialism.

\section{OUTLINE OF THE CREATIVE WORK}

\section{Theme}

Through this creative work, I want to show to the audience that how money actually controls our life unconsciously and money can lead us to wrong decisions. It is true that we can get acceptance with a lot of money, but it does not mean money can bring the happiness.

The background of the main character in my story will be both economically and mentally are not good. He is pressured by his big family especially his aunt, Ai Amei, that he needs to get a job soon, this influences him to think that the most important thing in this world is having a job and a lot of money. After he quite success and earned a lot of money, he spends his money to buy branded things and treat his family to show his prestige. His personalities change gradually because of the influences of the materialistic life. Another reason why he keeps earning money and buying branded things is because he already gets addicted to that lifestyle. In the middle of the story, the main character has to decide, and his materialistic life will influence how he thinks 
and how he decides something. At the end, there are people who remind him that money is not everything and money cannot make him happy, but the friendship is.

\section{Pitch}

1. Mike's aunt, Ai Amei, always humiliate Mike and his family because he has not got a job yet in his late $20 \mathrm{~s}$.

2. Mike needs to earn a lot of money to get acceptance from the big family, especially his aunt, Ai Amei, and he made a wrong decision to earn lots of money faster.

3. At the end, Mike lives a happier life, no longer seeing money as center of his life.

\section{Synopsis}

Mike is a jobless man in his late 20s, he struggles to make a living and he is under pressured by people around him, especially his big family. His aunt, Ai Amei, always compare Mike with her son, Ren because Ren has a great career and engages to a rich woman. Mike upsets and wants to proof himself to his big family by making a promise to buy Ren an expensive wedding gift. Struggle with his own promise, he is looking for an idea to get lots of money in a short time.

One day, he gets an idea to make a website for young adults, especially girls, who want to be listened. Basically, his jobs are accompanying girls who need a friend, listening to their stories, and comforting them through chatting. His website becomes popular and successful in six months. Getting a lot of money in a short time makes him wants to show off to people who underestimate him at the first place. He decides to buy branded things, newly brand car, and many other things. He unconsciously spends $50 \%$ of his savings and he becomes panic because he has not bought the wedding gift yet. He works really hard because the wedding is just less than a month.

Until one day, a girl requests to meet him in a person and gives him a good pay. He does not want to meet at first, but the girl keeps raising the prices. He gets surprised by amount of money that is offered by this girl. Without thinking twice, he makes a deal with the girl. The next day, he meets the girl and the girl tells him the story. Mike listens to her story with no interest because he thinks the girl is just hallucinating and making up some story. A week after that, Mike finds out that Dayu is kidnapped and will be killed if Mike does not come. Mike finally realizes that the girl is not making up the story.

\section{Characters}

\section{- Major Character:}

○ Michael Lim, 28 years old.

He is the first son in the family, he is in his late 20s but has not got a proper job yet. His big family, especially his aunt, Ai Amei, always look down on him and his family. Because of that, he finally starts a starts-up business and build a website called "The Listener". Mike can be categorized as a coward because he is often feeling afraid of something new and does not want to sacrifice himself. $\mathrm{He}$ is a person who talks before thinking that makes him regrets later. After his business failed twice, he cannot trust people easily. He is a person who thinks highly of prestige and pride. Eventually, his personalities change after he makes a lot of money by being a "listener", flows with the story and the conflict, he will experience a lot of unexpected things and change his mind set, personalities, and relationships. 
- Supporting Characters:

- Dayu, 17 years old.

Dayu is the daughter of Ida Bagus, she has a depression these past five years because she thinks that her father is not her father anymore. She used to be a cheerful girl and close to his Dad, but after her Dad becomes rich, she feels distance with his father. Eventually, she knows the truth of her father, she becomes a different person. She is just a naïve teenager who wants her old Dad back. She does not have someone to talk to, so she talks to The Listener.

\section{- Ben, 38 years old.}

Ben is the leader of the group. He was just a chef, but when he loses his wife, he is changed because he knows that Ida Bagus killed his wife. So, he wants to take a revenge to Ida Bagus. He seems tough, but actually he has a soft spot in his heart. He is smart in strategy, do research, and manipulation.

- Afu, 61 years old.

Mike's dad. He is a good father. He wants his children do what they want to do and be what they want to be. He does not demand anything to his children. $\mathrm{He}$ is a baker who is a hard-working person, but his big family treats him bad because the big family thinks that he cannot success. He has a deep sadness because his wife, the supporter of his life, is died. He always thinks that it is his fault that his wife cannot be cured. He is a person who will do anything for his kids and ignores the big family because he has enough of them.

○ Ai Amei, 58 years old.

Mike's Aunt, the mother of Ren. She is a typical Asian aunt who likes to meddle in someone's business. She is also a person who thinks that her family is the best and like to boast about her family. She likes to show off that her son is clever and successful. She thinks that money is everything and money is the parameter of being success.

- Kesatria, 32 years old.

Kesatria is another boy in this group. He is a brother from Ben's wife, that is why he works with Ben, to take a revenge to Ida Bagus. He always in front of his computer and rarely speak, but he speaks a lot about something interesting to him. Kesatria best at hacking and tracking, so he really a help for the crew because he mostly can access all of the websites.

- Maria, 23 years old.

Mike's little sister, but she is more mature than Mike. She loves Mike and always supports Mike.

- Vera, 26 years old.

Vera is Mike's cousin who is quite close to him. She likes talking to Mike.

- Extras

I Ida Bagus, 54 years old.

He is a man who is full of ambition, he came from a low-class family and he promised to himself that he never lived like that again. When he was child, he saw that rich people took control of his life, that is why he dreamt to be a rich person. After a long journey, he became rich, has a beautiful wife and daughter. He life seems complete and perfect. 


\section{Conflict}

The main conflicts in my screenplay are Man versus Society and Man versus Man. Man versus Society is how Mike versus his aunt, Ai Amei. In here, Ai Amei represents the society that pushes Mike to be successful by having lots of money. He tries to show people around him that he can be a useful man and can have lots of money. Later, after he gets a lot of money, he falls into a wrong decision and he will be struggle with the decision he had made. Man versus Man is about Mike and friends versus Ida Bagus, because Mike and the ragtag crew want to reveal the truth.

\section{Setting}

- Place

○ Bali, Indonesia

Bali is where Mike and his family live. I chose Bali because Bali has lots of outdoor spaces and I want to show the beauty of Bali to the audiences.

- Time

○ The time starts in March 2018, when Ren, Mike's cousin, holds an engagement.

\section{CONCLUSION}

I learnt several things through this creative work. Writing this creative work is surely not an easy thing to do because I have to put the creative sides and the logic sides at the same time. The creative sides in here I mean it is like the whole story, I have to make it different with others and I have to make it interesting meanwhile the logic sides are like the theory behind the story. I have to connect the theory and the story to answer my purpose and statement of the study. It is a hard thing to do because usually I make a story without a theory. However, actually I learnt so much through the theory because it helps me to develop my main character's personalities and the theory helps me to understand more about the topic that I want to bring up.

Second thing that I learnt through this creative work is time management. I have to write this creative thesis and work while working as a full timer at the coffeeshop. I may say that it is quite challenging because after I got home from work, sometimes I am too tired to write the script. Through this, I learnt to make deadlines in everything I do, to make it keep in track and make sure to finish the script. However, I also learnt that I should have fun to clear my mind at some point and should not be that workaholic because it helps me to get new ideas to create the script more interesting.

Lastly, in this process of writing the script, I learnt to be more detailed. Usually I am not a person who is detail oriented and often missed some parts, but, in this creative work, I have to be detail because it affects how the story will go. I have to be detail how to connect my story with the theory and I have to make sure that my creative work answers the statement of the problem. I think this is the hardest part in the making of this creative thesis. However, I am glad that I can learn something that can help me in the future.

\section{REFERENCES}

Alaydrus, H. (2017, November 3). Survei Membuktikan Generasi Milenial Lebih Suka Menonton TV | Ekonomi - Bisnis.com. Retrieved from https://ekonomi.bisnis.com/read/20171103/105/705870/survei-membuktikan-generasimilenial-lebih-suka-nonton-tv 
Miyamoto, K. (2016, April 19). Do you REALLY Know What Genre Your Screenplay Is? ScreenCraft. Retrieved from https://screencraft.org/2016/04/19/do-you-really-knowwhat-genre-your-screenplay-is/

Mulyono, F. (2011). Materialisme : Penyebab dan Konsekuensi.

Safiera, A. (2016, December 7). Konsumsi Barang Mewah di Indonesia Jadi Nomor Tiga Terbesar di Asia. Detik: Wolipop Lyfestyle. Retrieved from https://wolipop.detik.com/read/2016/12/07/194833/3365663/233/konsumsi-barangmewah-di-indonesia-jadi-nomor-tiga-terbesar-di-asia

Sheetz, T. K. (n.d.). A Modern Investigation of Status Consumption. Retrieved from https://artscimedia.case.edu/wpcontent/uploads/sites/57/2014/01/14235806/scheetzreport.pdf

Spina, F. (2017). Crime Films. Oxford Research Encyclopedia of Criminology and Criminal Justice. doi:10.1093/acrefore/9780190264079.013.30

Taher, A. P. (2017, December 28). Catatan Kinerja KPK di 2017: Data Kasus dan Latar Belakang Koruptor. Tirto.id. Retrieved from https://tirto.id/catatan-kinerja-kpk-di2017-data-kasus-dan-latar-belakang-koruptor-cCn5 